\title{
Broadening the urban sustainable energy diapason through energy recovery from waste: A feasibility study for the capital of Serbia
}

\author{
Ana Nikolic, Miljan Mikic, Zorana Naunovic* \\ University of Belgrade, Faculty of Civil Engineering, Bulevar kralja Aleksandra 73, 11000 Belgrade, Serbia
}

\section{A R T I C L E I N F O}

\section{Keywords:}

Waste to energy (WtE)

Mass burn incineration

Combined heat and power (CHP) system

Financial analysis

Economic analysis

\begin{abstract}
A B S T R A C T
Metropolitan areas are large consumers of energy and there is a growing need to broaden the urban sustainable energy diapason and increase the share of renewable and sustainable energy in overall energy consumption. This is especially important in countries such as Serbia that have limited domestic fossil fuel resources and rely on energy imports, from the environmental, financial and energy security points of view. In the Serbian capital of Belgrade electricity is produced in coal-fired power plants that have been shown to be vulnerable to flooding and the district heating system is reliant on imported natural gas. The objective of this work was to perform a feasibility study of a combined heat and power municipal solid waste mass burn incineration facility in Belgrade. The feasibility study included a financial and an economic analysis. The City of Belgrade has a developed district heating system and locating the incineration facility next to an existing heating plant would enable the utilization of the heat energy produced by incineration and substitution of a portion of the imported natural gas currently used for district heating. The contributions of energy derived from waste incineration to the total energy consumption in Belgrade were also evaluated. The feasibility study showed that municipal solid waste incineration would be financially and economically positive and viable.
\end{abstract}

\section{Introduction}

Metropolitan areas are large consumers of energy and there is a growing need to broaden the urban sustainable energy diapason and increase the share of renewable and sustainable energy use in overall energy consumption. This is especially important in countries such as Serbia that have limited domestic fossil fuel resources and rely on energy imports, from the environmental, financial and energy security points of view [1]. In the Serbian capital of Belgrade, electricity is produced in coal-fired power plants that have been shown to be vulnerable to flooding and the district heating system is reliant on imported natural gas.

The total primary energy supply in Serbia in 2014 was 13.58 million tonnes of oil equivalent (Mtoe) [2]. The share of different energy sources in the total primary energy supply in 2014 was as follows: coal $46.2 \%$; oil and oil products $24.5 \%$; natural gas $13.2 \%$; hydropower 7.4\%; solid biomass 7.7\%; electricity $1.0 \%$; and other renewables (solar, geothermal and biomass) $0.08 \%$ (Fig. 1) [2].

More than $90 \%$ of the required coal quantities are supplied predominantly through domestic lignite production while coke and higher calorific value coals are imported. Unlike coal, about $80 \%$ of oil and $70 \%$ of natural gas are supplied from imports. The country depends heavily on the import of energy commodities since its own reserves of oil and gas are limited [1]. The net energy import dependency in 2014 was $28 \%$ [2]. The development of energy production from renewable sources has been slow $[3,4]$. The total final energy consumption in Serbia in 2014 was 8.37 Mtoe. The largest energy consumers were the residential, transport and industrial sectors with a $33 \%, 25 \%$ and $24 \%$ share in final energy consumption, respectively [2].

Belgrade is located in central Serbia, at the confluence of the Sava and Danube rivers. The administrative area of Belgrade is divided into 17 municipalities with an estimated population of 1.8 million [5]. The total amount of waste collected in Belgrade was 584,532 $t$ in 2013 and $897,884 t$ in $2014[5,6]$. The large increase in the amount of waste deposited in 2014 was due to the collection of debris waste left after devastating floods that occurred in May 2014. 32,000 people were evacuated from their homes, there were 51 casualties and the material damage was estimated to more than two billion euro [7]. In Belgrade, the Municipality of Obrenovac was most heavily impacted. Serbia's largest coal mine in the Kolubara mining basin was also flooded. The lignite extracted from the Kolubara mining basin has a low calorific value of about $7 \mathrm{MJ} \mathrm{kg}^{-1}$ and it is used to supply three power plants located in the Belgrade administrative area [8]. Two of the power plants, "Nikola Tesla A" and "Nikola Tesla B" are the largest in Serbia

\footnotetext{
* Corresponding author.

E-mail address: znaunovic@grf.bg.ac.rs (Z. Naunovic).
} 


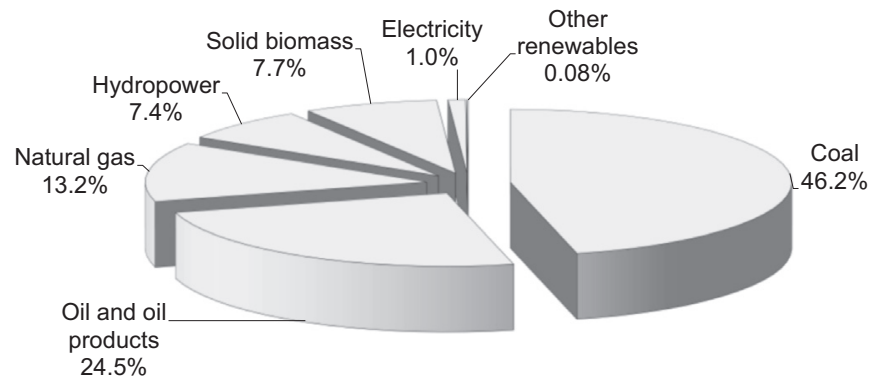

Fig. 1. The share of different energy sources in the total primary energy supply in Serbia in 2014 [2].

and are located in the municipality of Obrenovac, on the banks of the River Sava and were directly endangered by the floods. Belgrade's electric power supply system was compromised as it is predominantly reliant on the coal-fired power plants in Obrenovac. The Global Climate Risk Index listed Serbia as the country most impacted by climatic events in 2014 [9]. The energy sector in Serbia is also a major polluter in Serbia mainly due to the use of domestic lignite in power-plants that have dated emission abatement technologies [4]. The City of Belgrade consumed $6918 \mathrm{GW}$ h of electrical energy in 2014 and $2845 \mathrm{GW}$ h of thermal energy delivered through the district heating system during the 2014/2015 heating season [5]. The residential electrical energy demand was 54\% of the total electrical energy consumption in 2014. Utilizing the waste for energy recovery would contribute to energy security in Belgrade, as well as reduce the air pollution due to a partial substitution of energy production from fossil fuels.

The City of Belgrade, the capital of Serbia, has expressed interest in procuring a waste to energy (WtE) facility through a public-private partnership (PPP). Namely, a Request for qualification for a PPP project for the provision of services of treatment and disposal of residual municipal solid waste (MSW) was issued in August 2015 by the City of Belgrade followed by an invitation for participation in a competitive dialogue phase for five qualified bidders in February 2016 $[10,11]$. Options were left open to bidders to choose the type of waste combustion technology and assess the financial perspectives of the project $[10,11]$.

The objective of this work was to perform a feasibility study for a WtE project in Belgrade that allows all project stakeholders including the public to have insight into various aspects of developing a WtE facility. The feasibility study included a financial and an economic analysis. The financial analysis considers the project's financial inflows and outflows, and is done from the standpoint of the project owner. The economic analysis is done on behalf of the whole society and evaluates the social effects of the proposed project. The financial analysis results provide information on whether the proposed project is financially profitable, while the economic analyses results tell us if society is better off with or without the project. A proposed project is deemed sustainable if is profitable and beneficial to society. This approach has been previously applied to evaluate the effects of waste management scenarios [12-14]. A feasibility study must include a financial and an economic analysis if a project is to be considered for co-financing in operational programs of the European regional development fund and the Cohesion fund [15].

The chosen WtE combustion technology was mass burn grate incineration with energy recovered in the form of electricity and heat. Mass burn incinerators are used widely in Europe and worldwide and are designed with sufficient flexibility to cope with the wide range of waste compositions that they may receive $[16,17]$. Waste incinerators that produce steam for both electricity generation and district heating as combined heat and power systems have an overall higher energy conversion than when only electricity is generated [16]. The option of producing both electricity and heat is applicable as the City of Belgrade has a developed district heating system with an overall length of the heating route of $1420 \mathrm{~km}$ that services about half of the population in Belgrade [5]. The City of Belgrade provided the option of locating the incinerator next to the existing Cerak district heating plant [10]. When incineration is considered as a waste management option, the Waste Management Strategy for the period 2010-2019 [18] prescribes that energy recovery in the form of electricity and heat should be considered with the goal of increased energy efficiency.

\section{Materials and methods}

\subsection{Current MSW management practices}

Waste in Belgrade is collected by seven different public utility companies and is disposed of at five unsanitary landfills. The largest public utility company is called "Gradska cistoca" ("City Sanitation") and services eleven municipalities that generate about $85 \%$ of the municipal solid waste in Belgrade. Current municipal waste management practices conducted by City Sanitation include limited recycling and waste disposal at the Vinca unsanitary landfill located $15 \mathrm{~km}$ from Belgrade, on the right bank of the River Danube. The landfill site has been in operation since 1977, it occupies an area of about 70 ha where the landfill body has an area of 45 ha and a height of $5-50 \mathrm{~m}$. There is no collection of landfill gas and leachate drains though a canal into a natural swamp within the Danube riverbed. The City of Belgrade is planning to perform remediation works with landfill gas capture at the existing unsanitary landfill site in Vinca and construct a new sanitary landfill for the disposal of WtE treatment process residues, also through the PPP project [10]. Waste collection, primary transport and recycling of source-separated recyclables from households, commercial properties and other similar institutions will continue to be operated by the City's designated public utility company and will not be a part of the PPP project [10].

\subsection{MSW characterisation}

It is planned that residual MSW (waste after source-separation of recyclable materials has been carried out) from 13 municipalities that generate up to $90 \%$ of the total waste in the City of Belgrade will be treated in the incinerator facility as four municipalities have adopted a separate regional waste management plan. MSW from these municipalities is made up of approximately $80 \%$ household waste and $20 \%$ commercial waste. Projected municipal waste quantities from the 13 participating municipalities are given in Fig. 2 from the expected year of start of commercial operations at the incinerator facility up to the end of the operational period. Recycling rates were projected to increase until they reach a steady rate of $23 \%$ for household waste

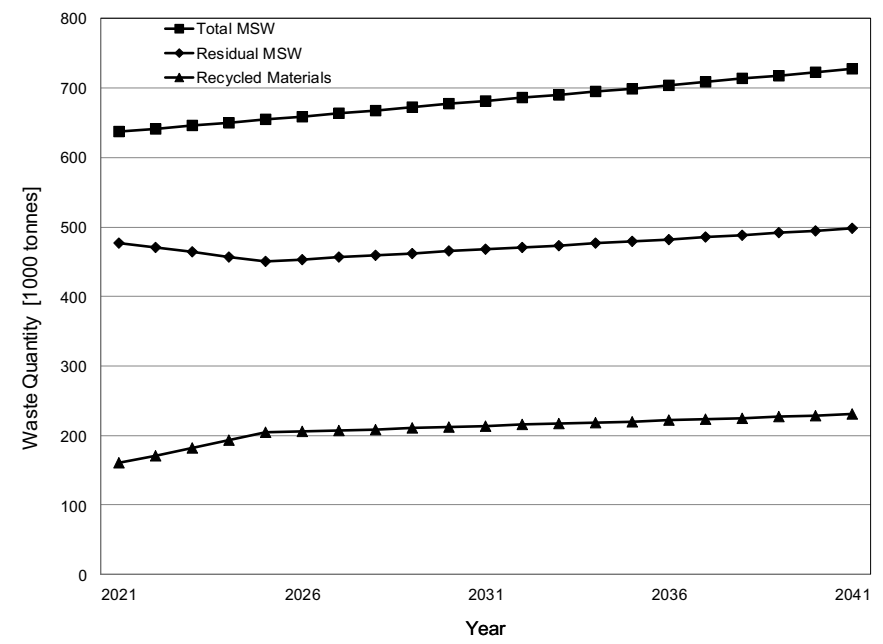

Fig. 2. Projected municipal waste quantities. 
Table 1

MSW composition and lower heating values.

\begin{tabular}{llll}
\hline Waste Fraction [\%] & MSW & Residual MSW & LHV (wet basis) $\left[\mathrm{MJ} \mathrm{kg}^{-1}\right]$ \\
\hline Food waste & 26.3 & 38.8 & 3.8 \\
Paper/ Cardboard & 22.2 & 8.2 & 12.2 \\
Plastics & 13.9 & 9.2 & 35.3 \\
Textile & 3.9 & 5.8 & 18.5 \\
Diapers & 4.0 & 5.9 & 11.1 \\
Leather & 1.1 & 1.6 & 22.9 \\
Yard waste & 6.7 & 9.9 & 5.9 \\
Wood & 1.1 & 0.6 & 15.6 \\
Glass & 5.5 & 2.0 & 0 \\
Metals & 3.6 & 1.3 & 0 \\
Inert & 11.2 & 16.5 & 0 \\
Hazardous waste & 0.5 & 0 & \\
Total & 100 & 100 & \\
\hline
\end{tabular}

and $55 \%$ for commercial waste, resulting in an overall MSW recycling rate of 32\% [10]. Total MSW waste generation, recycling forecasts and composition data were provided by the City of Belgrade [10], while the composition and heating value of residual MSW were calculated by the authors.

Table 1 presents total and residual MSW composition data and the lower heating values for individual waste components. The estimation of the composition of residual MSW was based on the recycling rates of packaging waste components prescribed in the adopted Proposal for a Directive of the European Parliament and of the Council amending Directive 94/62/EC on packaging and packaging waste [19]. This proposal is a part of the adopted EU Circular Economy package and it sets out the following targets for the reduction of the waste components specified herein by 2025: $75 \%$ for paper and cardboard; $55 \%$ for plastics; $75 \%$ for glass; $75 \%$ for metals; and $60 \%$ for wood. Serbia is achieving the recycling goals defined in the national Plan for the reduction of packaging waste [20], mostly by recycling waste from the commercial sector [21]; there is much room for improvement in the household waste recycling sector as only $3 \%$ of households in Belgrade participate in recycling programs [22]. There is sufficient processing capacity in Serbia for all types of packaging waste recyclables.

For the purposes of calculating the heating value of residual MSW, it was assumed that the stated recycling goals would be fulfilled and that hazardous waste would be source-separated and not incinerated. The lower heating values (LHV) for food waste, paper, cardboard and plastics were adopted from Athanasiou et al. [23], who used data from Komilis at al. [24]. The LHV for other MSW components were taken from the work conducted by Riber et al. [25] and presented in detail in Christensen [26]. The LHV of MSW prior to recycling and residual MSW were calculated to be $10.6 \mathrm{MJ} \mathrm{kg}^{-1}$ and $8.5 \mathrm{MJ} \mathrm{kg}^{-1}$, respectively.

\subsection{Energy generation}

The energy yield from a combined heat and power incinerator facility was calculated based on recommendations from Rand et al. [27] where residual MSW with a LVH of $8.5 \mathrm{MJ} \mathrm{kg}^{-1}$ yields $0.47 \mathrm{MWh}$ of electrical energy and $1.53 \mathrm{MW}$ h of heat per tonne of residual MSW. Calculations of the annual quantities of electricity and heat produced were based on these yields and the annual forecasts of residual MSW quantities. For example, in its first year of operation, the incinerator produces $224 \mathrm{GW} \mathrm{h}$ of electrical energy and $729 \mathrm{GW} \mathrm{h}$ of heat or the equivalent of $6 \%$ of the electrical household demand in 2014 and $26 \%$ of the thermal energy delivered during the 2014/2015 heating season in Belgrade [5]. These new capacities would fulfil the goals for obtaining energy from waste set in the National Renewable Energy Action Plan for Serbia [28].

\subsection{Financial, economic and sensitivity analyses}

The financial analysis checks the project's ability to generate return on investment. If the project can generate a positive return on the investment, it is deemed financially positive and profitable. The financial analysis is done by expressing all project financial inflows and outflows and using the project cash flow forecast to calculate suitable financial performance indicators. A financial discount rate is used in the calculation to determine the present value of future cash flows. The performance indicators, the financial net present value of investment (FNPV(C)) and the financial rate of return of the investment (FRR(C)), compare investment costs to net revenues and measure the extent to which the project net revenues are able to repay the investment [29]. FNPV(C) is the sum which results when the expected discounted inflows are deducted from the expected discounted outflows. FRR(C) is defined as the discount rate that produces zero FNPV(C). When FNPV(C) is positive and FRR (C) is higher than the applied financial discount rate, the project is financially positive and profitable [29].

The economic analysis evaluates the social effects of the proposed project on behalf of the whole society instead of solely the project owner, as is done in the financial analysis [29]. In the economic analysis, benefits are defined as increases in human wellbeing and costs as reductions in human wellbeing $[29,30]$. A project is beneficial to society if the benefits exceed the costs. This is evaluated by converting costs and benefits into monetary units and calculating suitable economic performance indicators. The present value of future costs and benefits is appraised by using a social discount rate that reflects the social view on how future costs and benefits and costs should be valued against present ones. The project economic performance can be measured by the following indicators: Economic Net Present Value (ENPV) and the Economic Rate of Return (ERR). The ENPV is the difference between the discounted total benefits and costs to society, and the ERR is the rate that produces a zero value for the ENVP. The project is economically positive and beneficial to society if the ENVP is positive and the ERR is higher than the adopted social discount rate.

The standard approach for economic analysis, consistent with international practice, consists of four steps [29]: conversion of financial inflows and outflows to their economic values, monetisation of non-market impacts, discounting of net cash flow and calculation of economic performance indicators. Non-market impacts are the impacts or effects that the implementation of the project will have on project users and society as a whole. Non-market effects are the social effects of the project that can be negative and positive, and as such, are classified as social costs and benefits. The social costs and benefits are expressed in monetary terms and included in the economic analysis. In the context of an economic analysis, typical social effects are the impacts that the project will have on the environment, health and human wellbeing, locally and globally.

In addition, the sensitivity of the input parameters for the financial and economic analyses was examined and a scenario analysis was conducted. In the sensitivity analysis, the influence of the changes in the values of input parameters on the output indicators was examined.

\section{Results and discussion}

\subsection{Financial analysis}

The tender documents for dialogue phase for the PPP project issued by the City of Belgrade state that the term of contract is up to 25 years from the effective date of the contact [11]. The PPP contract is expected to be signed in early 2017 which was taken as the start of a 25-year life cycle that includes four years for project implementation and a 21-year operation period starting in 2021. The chosen reference periods are in line with European Commission and World Bank recommendations $[27,29]$. The financial discount rate was adopted as $4.5 \%$ [31]. 
The maximum amount of residual MSW is generated at the end of the project life cycle in 2041 and is equal to 498,000 t (Fig. 1). The adopted nominal capacity (NC) of the incinerator facility was $550,000 \mathrm{t}$ per year to include a safety factor of $10 \%$. The initial capital investment (I) and annual operating cost (OC) were calculated using the cost functions developed by Tsilemou and Panagiotakopoulos [32] that are based on a survey of 32 mass burn MSW incinerator facilities across Europe:

$I=5000 \bullet N C^{0.8}[€] O C=700 \bullet N C^{-0.3}\left[€ t^{-1}\right]$

All monetary values were adjusted to November 2015 with the average inflation rate of $2.03 \%$ [33]. As the City of Belgrade will provide the land for the incinerator facility within the PPP [10], the capital investment cost was decreased by $2 \%$ to account for the value of land acquisition. The investment capital cost was calculated to be $€ 239$ million.

The operating costs were calculated to be $€ 16.5$ per tonne of residual MSW or $€ 7.9$ million and $€ 8.2$ million in the first and last year of operation, respectively. The additional financial outflows included:

1. the replacement costs (RC) of short life facility components in the 19 th year of project life cycle (adopted as a $75 \%$ of the facility and equipment costs); and

2. the clearance and decontamination cost (CDC) of the project site at the end of the operational period (assumed to be $4 \%$ of the initial capital investment or $€ 9.5$ million).

The financial inflow consisted of the waste treatment and recovered energy revenues. The monthly MSW collection and disposal fee in 2014 was $€ 0.89$ per resident with a payment rate of $95 \%$ [22]. For purposes of this analysis, the assumed monthly incinerator gate fee was $€ 1$ per resident. The total monthly waste management fee (collection, disposal and treatment) was $€ 1.89$ per resident or $€ 5.2$ per household, which equates to $0.9 \%$ of the average household income in Belgrade [5]. In Wilson et al. [34] it is stated that if the cost per household for the entire waste management system is less than $1 \%$ of household income in lowincome countries or $2 \%$ in middle-income countries, the cost will likely be affordable.

The annual waste treatment revenue was calculated with respect to the expected population growth for Belgrade from the publication "Population Projections of the Republic of Serbia 2011-2041" [35]. The annual residual MSW incineration fees were calculated by multiplying the annual population projections by the incinerator gate fee and resulted in annual revenues in the range of $€ 19.4$ to $€ 20.7$ million.

The recovered energy revenues were based on the sale of electricity and heat. A feed-in tariff for electricity generated from WtE facilities was prescribed in 2013 as $€ 85.7$ per MWh [36]. The monetary value was adjusted using an inflation rate of 1.99\% (February 2013November 2015) to $€ 87.4$ per MW h. The annual electricity revenues were calculated to be from $€ 18.8$ to $€ 19.5$ million during the project cycle, assuming the payment rate would remain at the current level of $96 \%$.

The current retail price of heat energy delivered via the district heating system in Belgrade is $€ 56.3$ per MW $\mathrm{h}$ [37]. The production price of thermal energy as provided by the Cerak thermal power plant is $€ 42$ per MW h. The heat production price is relatively high due to the high cost of imported natural gas that is used as fuel, which is currently about $€ 0.3$ per cubic meter [38]. It was assumed that the heat generated by the MSW incinerator could be sold to the City of Belgrade at the current natural gas based heat production price of $€ 42$ per MWh per the substitution principle. The recovered heat annual revenue was between $€ 26.6$ and $€ 27.6$ million, with the current payment rate of $87 \%$ [39]. The residual value of the investment was conservatively set to zero [29]. The allocation of financial outflows and inflows within the project life cycle and the resulting indicators are shown in Table 2.
In this analysis, the FNPV(C) proved to be positive and very high (€360 million) and the FRR(C) is significantly higher than the applied financial discount rate (19.6\% compared to $4.5 \%)$, implying that the generated revenues are considerably higher than the investment costs and that the project is financially positive and profitable. The results obtained from the financial analysis show that the project is a good candidate for a PPP. However, the question of whether society is better off with or without the project remained to be assessed by an economic analysis.

\subsection{Economic analysis}

The first step of an economic analysis is to convert financial inflows and outflows to their economic values. The financial analysis does not account for the effects that the local social context and conditions may have on project inflows and outflows, such as demographic trends, unemployment rates, taxation and social security legislative. These influences were evaluated and used in the calculation of conversion factors that were used to multiply the financial inflows and outflows and obtain their economic values. The economic values better reflect the project inflows and outflows in a specified local setting.

The conversion factors were calculated based on the following principles [29]:

1. when project inputs were tradable goods, border prices were used;

2. a standard conversion factor (SCF) was used for non-tradable goods;

3. a shadow wage (SWR) was calculated for manpower wages.

A SCF measures the average difference between world and domestic prices and can be calculated with the following formula [29]:

$S C F=\frac{M+X}{M+X+T M}$

where $M$ is the total value of import at cost, insurance and freight prices; $\mathrm{X}$ is the total value of export at free on board prices; and TM is the total value of duties on import. The SCF for Serbia was calculated as 0.98 , where values for $\mathrm{M}, \mathrm{X}$ and TM were taken from the Statistical yearbook of Belgrade 2014 [5] and the Customs Administration of the Ministry of Finance [40].

Shadow wages for manpower were calculated for skilled and nonskilled manpower separately according to the following formula:

$S W R=W(1-T)(1-u)$

where $\mathrm{W}$ is market wage, $\mathrm{T}$ is the income taxation and $\mathrm{u}$ is unemployment rate. In Serbia, $\mathrm{T}$ is $47.8 \%$ [ 41 ] and $\mathrm{u}$ is $15.4 \%$ and $2.45 \%$ for skilled and non-skilled manpower, respectively [42]. The resulting value of skilled and non-skilled manpower conversion factors were 0.44 and 0.51 respectively. Other conversion factors for outflows and inflows were calculated based on the percentage of costs for skilled and non-skilled manpower, materials and equipment. All conversion factor values are shown in Table 3 .

A discount rate, termed the social discount rate, is also used in the economic analysis. The social discount rate reflects the social view on how future benefits and costs should be valued against present ones. The recommended social discount rate for infrastructure projects in Serbia is $5.5 \%$ [43].

The second step in an economic analysis is the monetisation of nonmarket or social effects of the project, such as the effects that the project will have on the environment, health and human wellbeing, locally and globally. When best available incineration and flue gas treatment technologies are applied, as is the case in this study and has been accounted for in the capital investment and operating costs, waste incineration does not cause any detectable health risks for the population living in the vicinity [44]. The stringent air emission limit values for waste incinerator facilities are prescribed in the Directive 2000/76/ $\mathrm{EC}$ of the European Parliament and of the Council on the Incineration 
Table 2

Financial analysis (in millions of $€$, zero values are not shown).

\begin{tabular}{|c|c|c|c|c|c|c|c|c|c|c|c|c|c|c|}
\hline Financial discount rate & $4.5 \%$ & & & & & & & & & & & & & \\
\hline Year & 1 & 2 & 3 & 4 & 5 & 6 & 7 & 8 & 9 & 10 & 15 & 19 & 20 & 25 \\
\hline I & 8.9 & 10.6 & 105.9 & 113.2 & & & & & & & & & & \\
\hline $\mathrm{OC}$ & & & & & 7.9 & 7.8 & 7.7 & 7.6 & 7.4 & 7.5 & 7.7 & 7.9 & 8.0 & 8.2 \\
\hline $\mathrm{RC}$ & & & & & & & & & & & & 164.3 & & \\
\hline $\mathrm{CDC}$ & & & & & & & & & & & & & & 9.5 \\
\hline Total Outflow (TO) & 8.9 & 10.6 & 105.9 & 113.2 & 7.9 & 7.8 & 7.7 & 7.6 & 7.4 & 7.5 & 7.7 & 172.3 & 8.0 & 17.8 \\
\hline Treatment revenue & & & & & 19.4 & 19.5 & 19.6 & 19.6 & 19.7 & 19.8 & 20.1 & 20.3 & 20.3 & 20.7 \\
\hline Electricity revenue & & & & & 18.8 & 18.8 & 18.5 & 18.3 & 18.0 & 17.8 & 18.3 & 18.8 & 18.9 & 19.5 \\
\hline Heat revenue & & & & & 26.6 & 26.6 & 26.3 & 25.9 & 25.6 & 25.2 & 26.0 & 26.6 & 26.8 & 27.6 \\
\hline Total Inflow (TI) & & & & & 64.9 & 64.9 & 64.4 & 63.9 & 63.3 & 62.7 & 64.4 & 65.7 & 66.0 & 67.8 \\
\hline $\mathrm{TI}-\mathrm{TO}$ & -8.9 & -10.6 & -105.9 & -113.2 & 57.0 & 57.2 & 56.7 & 56.3 & 55.9 & 55.2 & 56.7 & -106.6 & 58.0 & 50.1 \\
\hline FNPV(C) & 360 & & & & & & & & & & & & & \\
\hline $\mathrm{FRR}(\mathrm{C})$ & $19.6 \%$ & & & & & & & & & & & & & \\
\hline
\end{tabular}

Table 3

Conversion factors (CF) for the economic analysis.

\begin{tabular}{|c|c|c|}
\hline Type of cost & $\mathbf{C F}$ & Comment \\
\hline Design & 0.44 & $100 \%$ skilled labour \\
\hline Construction & 0.64 & $\begin{array}{l}40 \% \text { construction materials }(\mathrm{CF}=\mathrm{SCF}), 5 \% \\
\text { skilled labour, } 45 \% \text { non-skilled labour, } \\
10 \% \text { profit }\end{array}$ \\
\hline Equipment & 1.00 & Imported without taxes and tariffs \\
\hline Investment (weighted) & 0.88 & $\begin{array}{l}7 \% \text { design, } 23 \% \text { construction, } 70 \% \\
\text { equipment }\end{array}$ \\
\hline Labour and administration & 0.56 & $\begin{array}{l}54 \% \text { non-skilled labour, } 31 \% \text { skilled } \\
\text { labour, } 15 \% \text { materials }\end{array}$ \\
\hline Materials & 0.98 & traded good; $\mathrm{CF}=\mathrm{SCF}$ \\
\hline Energy and water services & 0.98 & $\mathrm{SCF}$ \\
\hline Maintenance & 0.92 & $\begin{array}{l}5 \% \text { skilled labour, } 10 \% \text { non-skilled labour, } \\
85 \% \text { equipment }\end{array}$ \\
\hline $\begin{array}{l}\text { Operation and maintenance } \\
\text { (weighted) }\end{array}$ & 0.86 & $\begin{array}{l}25 \% \text { labour and administration, } 40 \% \\
\text { energy and materials, } 35 \% \text { maintenance }\end{array}$ \\
\hline Residual value & 0.88 & $100 \%$ investment (weighted) \\
\hline Treatment services & 0.98 & $\mathrm{SCF}$ \\
\hline $\begin{array}{l}\text { Clearance and } \\
\text { decontamination }\end{array}$ & 0.60 & $\begin{array}{l}10 \% \text { skilled labour, } 70 \% \text { non-skilled } \\
\text { labour, } 20 \% \text { materials }\end{array}$ \\
\hline
\end{tabular}

of Waste and have been transposed into Serbian legislation $[45,46]$. However, the emission of greenhouse gases (GHG) from waste incinerators is not covered by the legislation. The emission of GHG from waste incineration represents a negative social effect or social cost with a global impact. To evaluate if a project will be beneficial to society, the negative social effects or costs have to be compared to the positive social effects or benefits by monetisation of all social effects.

For the case of waste incineration, the positive social effects or benefits include: the diversion of waste from landfills, the associated saved landfill space and avoided emissions of GHG; and the substitution of energy production from fossil fuels and the associated avoided emissions of GHG $[29,47,48]$.

The incineration of waste results in the diversion of waste from landfills and a positive social effect in the form of saved landfill space and land conservation. To monetise this social benefit, the landfill footprint required to accept waste that would otherwise be incinerated was multiplied by the prescribed cost of land designated for expropriation; the expropriated land is to be used for the construction of a new landfill within the scope of the PPP project [10]. The landfill footprint was calculated based on the conceptual landfill design specified in the Local waste management plan for the City of Belgrade, where the density of compacted waste was $0.8 \mathrm{t}$ of waste per cubic meter and the height available for landfilling of waste without daily and final covers was $18 \mathrm{~m}$ [49]. The prescribed cost of land is $€ 0.85$ per square meter [50]. The resulting social benefits are included in Table 4 .

The social effect resulting from GHG emissions was appraised by quantifying the GHG emissions from waste incineration, as a social cost, and the avoided GHG from landfills and fossil fuel based thermal power plants that produce electricity and heat, as a social benefit. The monetary value of GHG emitted to the atmosphere was calculated by multiplying the amount of emissions $\left(\mathrm{CO}_{2}\right.$-equivalents per year) by their unit cost expressed in Euro per tonne. The unit cost of the emissions of GHG was $€ 32$ and $€ 50.5$ per tonne of $\mathrm{CO}_{2}$-eq at the start and end of the project cycle, respectively, as recommended by European Investment Bank [51].

The avoided emissions of GHG due to the diversion of biodegradable waste from landfills were quantified by calculating the difference between the emissions of GHG that emanate from landfills and the WtE facility based on data from the European Commission [29]. The landfill emissions of GHG were $0.67 \mathrm{t} \mathrm{CO}_{2}$-eq per tonne of landfilled waste at the start of the project cycle and decreased to $0.62 \mathrm{t} \mathrm{CO}_{2}$-eq per tonne of waste at the end of the project cycle, due the assumed changes in the composition of residual MSW where the organic and plastic waste contents will decrease and increase, respectively. The emissions of GHG from the WtE facility ranged from 0.47 to $0.55 \mathrm{t} \mathrm{CO}_{2}$-eq per tonne of incinerated waste. The calculated difference between the GHG that emanate from landfills and the WtE facility ranged from 0.2 to $0.07 \mathrm{t}$ $\mathrm{CO}_{2}$-eq per tonne of waste during the project life cycle. The avoided emissions of GHG from the partial replacement of fossil fuels used for the generation of heat and electricity were quantified based on the GHG emission factor for natural gas based district heating systems and lignite of $0.26 \mathrm{~kg} \mathrm{CO}_{2}$-eq per $\mathrm{kWh}$ and $1.7 \mathrm{~kg} \mathrm{CO}$-eq per $\mathrm{kWh}$, respectively [52].

The calculation of economic performance indicators is shown in Table 4. The calculated ENPV is higher than zero ( $€ 616$ million). ERR is significantly higher than adopted social discount rate $32.2 \%$ compared to 5.5\%). As the ERR is higher than adopted social discount rate and ENPV has a positive value, the project is economically positive and beneficial to society.

\subsection{Sensitivity analysis}

A sensitivity analysis was conducted to examine the influence of changes in the values of project variables on financial (FNPV(C)) and economic performance indicators (ENPV). Elasticity is the percentage of change in the net present value indicator for a $\pm 1 \%$ change in a variable [29]. Critical variables are the variables for which a variation of $\pm 1 \%$ of the adopted value leads to variation of more than $1 \%$ in the net present value indicator [29]. The results of the sensitivity analysis are presented in Table 5.

The elasticity calculation for both the financial and economic analyses showed that only the waste input quantities and to a lesser extent the discount rates could be labelled as critical variables. However, the change needed to turn the project financially and/or economically negative for each considered variable is very high and out of range of any probable, even the most pessimistic assessment. Spider diagrams illustrating the elasticity of FNPV(C) and ENPV for a 25\% change in value of the critical variables are presented as Fig. 3. 
Table 4

Economic analysis (in millions of $€$, zero values are not shown).

\begin{tabular}{|c|c|c|c|c|c|c|c|c|c|c|c|c|c|c|}
\hline Social discount rate & $5.5 \%$ & & & & & & & & & & & & & \\
\hline Year & 1 & 2 & 3 & 4 & 5 & 6 & 7 & 8 & 9 & 10 & 15 & 19 & 20 & 25 \\
\hline I & 7.8 & 9.3 & 93.1 & 99.5 & & & & & & & & & & \\
\hline $\mathrm{OC}$ & & & & & 6.7 & 6.6 & 6.6 & 6.5 & 6.4 & 6.4 & 6.6 & 6.8 & 6.8 & 7.0 \\
\hline $\mathrm{RC}$ & & & & & & & & & & & & 144.4 & & \\
\hline $\mathrm{CDC}$ & & & & & & & & & & & & & & 5.7 \\
\hline Total economic cost (TEC) & 7.8 & 9.3 & 93.1 & 99.5 & 6.7 & 6.6 & 6.6 & 6.5 & 6.4 & 6.4 & 6.6 & 151.2 & 6.8 & 12.7 \\
\hline Treatment revenue & & & & & 19.1 & 19.1 & 19.2 & 19.2 & 19.3 & 19.4 & 19.7 & 19.9 & 19.9 & 20.3 \\
\hline Electricity revenue & & & & & 18.8 & 18.8 & 18.5 & 18.3 & 18.0 & 17.8 & 18.3 & 18.8 & 18.9 & 19.5 \\
\hline Heat revenue & & & & & 26.6 & 26.6 & 26.3 & 25.9 & 25.6 & 25.2 & 26.0 & 26.6 & 26.8 & 27.6 \\
\hline$\underline{\text { Saved landfill space }}$ & & & & & $\underline{0.03}$ & $\underline{0.03}$ & $\underline{0.03}$ & $\underline{0.03}$ & $\underline{0.03}$ & $\underline{0.03}$ & $\underline{0.03}$ & $\underline{0.03}$ & $\underline{0.03}$ & $\underline{0.03}$ \\
\hline $\begin{array}{l}\text { Avoided emissions of GHG due to diversion of biodegradable waste from } \\
\text { landfill }\end{array}$ & & & & & 3.4 & 3.4 & 3.3 & 3.2 & 3.2 & 3.2 & 3.0 & 2.7 & 2.6 & 1.8 \\
\hline $\begin{array}{l}\text { Avoided emissions of GHG from partial replacement of fossil fuels used for } \\
\text { generation of heat }\end{array}$ & & & & & 6.8 & 6.9 & 7.0 & 7.1 & 7.2 & 7.4 & 8.5 & 9.1 & 9.2 & 10.0 \\
\hline $\begin{array}{l}\text { Avoided emissions of GHG from partial replacement of fossil fuels used for } \\
\text { generation of electricity }\end{array}$ & & & & & 13.7 & 13.9 & 14.1 & 14.3 & 14.4 & 14.9 & 17.0 & 18.2 & 18.5 & 20.1 \\
\hline Total economic benefit (TEB) & & & & & $\underline{88.5}$ & $\underline{88.2}$ & $\underline{87.8}$ & $\underline{87.5}$ & $\underline{87.1}$ & $\underline{88.1}$ & $\underline{92.7}$ & $\underline{95.5}$ & $\underline{96.2}$ & $\underline{99.6}$ \\
\hline TEB-TEC & -7.8 & -9.3 & -93.1 & -99.5 & $\underline{81.8}$ & $\overline{81.5}$ & $\underline{81.3}$ & $\underline{81.0}$ & $\underline{80.7}$ & $\underline{81.6}$ & $\underline{86.1}$ & -53.1 & $\underline{89.4}$ & $\underline{86.9}$ \\
\hline ENPV & $\underline{616}$ & & & & & & & & & & & & & \\
\hline ERR & $\overline{32.2} \%$ & & & & & & & & & & & & & \\
\hline
\end{tabular}

Table 5

FNPV (C) and ENPV elasticity values.

\begin{tabular}{lll}
\hline Variable & FNPV (C) elasticity & ENPV elasticity \\
\hline Financial discount rate & $-0.78 \%$ & \\
Social discount rate & & $-0.81 \%$ \\
I & $-0.78 \%$ & $-0.37 \%$ \\
OC & $-0.24 \%$ & $-0.11 \%$ \\
Waste input & $1.16 \%$ & $1.05 \%$ \\
Gate fee & $0.62 \%$ & $0.31 \%$ \\
Electricity revenue & $0.58 \%$ & $0.30 \%$ \\
Heat revenue & $0.82 \%$ & $0.42 \%$ \\
Shadow price of $\mathrm{CO}_{2}$ & & $0.33 \%$ \\
Payment rate gate fee & $0.62 \%$ & $0.31 \%$ \\
Payment rate heat & $0.82 \%$ & $0.42 \%$ \\
Payment rate electricity & $0.58 \%$ & $0.30 \%$ \\
\hline
\end{tabular}

The spider diagrams in Fig. 3 illustrate that the FNPV(C) and ENPV exhibit low elasticities and remain positive and high within the analysed range of critical input variables.

The impact of a potential simultaneous change of several variables was also assessed and no probable scenario was found that could lead the project to become financially or economically negative. The most pessimistic scenario analysed included the following simultaneous changes:
1. a $30 \%$ increase in both the initial capital investment and operating costs;

2. a $20 \%$ increase of the financial discount rate and social discount rate;

3. a $20 \%$ decrease in waste input;

4. a $30 \%$ decrease of the gate fee; and

5 . a $30 \%$ decrease of the heat price.

Even within the presented pessimistic scenario, the project remains financially and economically positive, with the $\mathrm{FNPV}(\mathrm{C})$ of $€ 12.8$ million and ENPV of $€ 229.4$ million.

\section{Conclusions}

A comprehensive project feasibility study was performed for a combined heat and power mass burn incineration facility for the City of Belgrade in Serbia. MSW characterisation showed that the LHV of the residual MSW fraction was $8.5 \mathrm{MJ} \mathrm{kg}^{-1}$ and that the energy generation potential was $0.47 \mathrm{MWh}$ of electrical energy and $1.53 \mathrm{MW} \mathrm{h}$ of heat per tonne of residual MSW. The City of Belgrade has a developed district heating system and locating the WtE facility next to an existing thermal power plant would enable the utilization of the heat energy produced by incineration and substitution of a portion of the imported natural gas currently used for district heating. Electrical energy

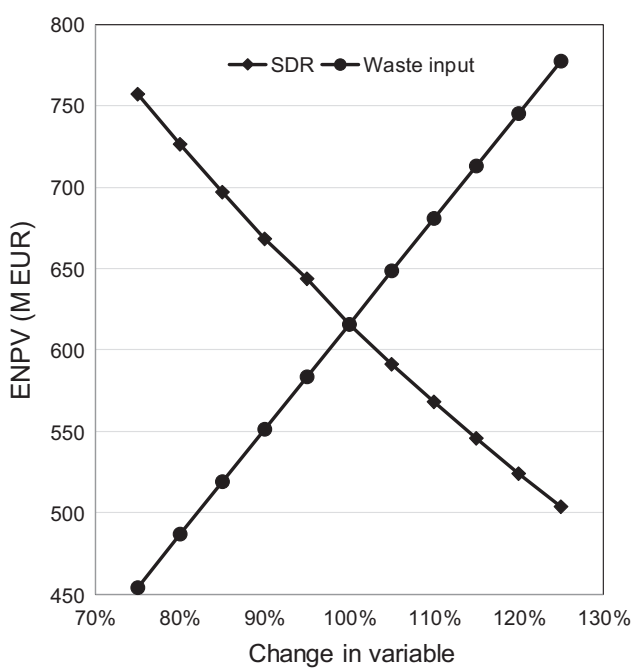

Fig. 3. FNPV(C) and ENPV elasticity changes. 
produced by incineration will reduce the amount of coal burned in power plants that currently supply Belgrade with electricity. The financial, economic and sensitivity analyses, showed that the project was financially and economically positive, viable and very resilient to changes in the values of project variables. The analysis provides evidence in support of choosing PPP as a method of project financing and development.

The Belgrade WtE facility project is a first-of-its-kind in the region, both as a WtE facility and a PPP in the energy sector. The presented work has shown explicitly and in detail how a WtE project feasibility study with a financial and an economic analysis should be conducted with tangible terms and parameters. It can serve as a primer on conducting WtE feasibility studies for cities and urban areas in the region that do not have developed WtE systems. The presented approach can be used by researchers, consultants, policy and decision makers and practitioners alike when considering waste incineration as an integral part of a waste management system and as a renewable and sustainable energy source. A feasibility study must include a financial and an economic analysis if a project is to be considered for cofinancing in operational programs of the European regional development fund and the Cohesion fund.

\section{References}

[1] Bajić BŽ, Dodić SN, Vučurović DG, Dodić JM, Grahovac JA. Waste-to-energy status in Serbia. Renew Sustain Energy Rev 2015;50:1437-44.

[2] Statistical Office of the Republic of Serbia. Energy balances 2014. Belgrade, Serbia; 2016.

[3] Bjelic IB, Ciric RM. Optimal distributed generation planning at a local level - A review of Serbian renewable energy development. Renew Sustain Energy Rev 2014;39:79-86.

[4] Karakosta C, Flouri M, Dimopoulou S, Psarras J. Analysis of renewable energy progress in the western Balkan countries: Bosnia-Herzegovina and Serbia. Renew Sustain Energy Rev 2012;16(7):5166-75.

[5] Institute for Informatics and Statistics. Statistical yearbook of Belgrade 2014. Belgrade, Serbia; 2015.

[6] Institute for Informatics and Statistics. Statistical yearbook of Belgrade 2013. Belgrade, Serbia; 2014

[7] Vujadinovic M, Vukovic A, Cvetkovic B, Pejanovic G, Nickovic S, Djurdjevic V., et al. High-resolution numerical modeling of meteorological and hydrological conditions during May 2014 floods in Serbia. Geophysical Research Abstracts 17:7602. Proceeding of the European Geosciences Union General Assembly; 2015 Apr 1217; Vienna, Austria. Göttingen, Germany: Copernicus Publications; 2015.

[8] City of Belgrade. Energy development strategy of the City of Belgrade. Belgrade, Serbia; 2008.

[9] Kreft S, Eckstein D, Dorsch L, Fischer L. Global climate risk index. Bonn, Germany: Germanwatch; 2015. p. 2016.

[10] City of Belgrade. Request for qualification for the PPP project for the City of Belgrade for the provision of services of treatment and disposal of residual municipal solid waste. Belgrade, Serbia; 2015.

[11] City of Belgrade. Tender documents for dialogue phase for the PPP project for the City of Belgrade for the provision of services of treatment and disposal of residual solid waste. Belgrade, Serbia; 2016.

[12] Allesch A, Brunner PH. Assessment methods for solid waste management: a literature review. Waste Manag Res 2014;32(6):461-73.

[13] Jamasb T, Nepal R. Issues and options in waste management: a social cost-benefit analysis of waste-to-energy in the UK. Resour Conserv Recycl 2010;54:1341-52.

[14] Mikic M, Naunovic Z. A sustainability analysis of an incineration project in Serbia. Waste Manag Res 2013;31(11):1102-9.

[15] Regulation (EU). No 1303/2013 of the European Parliament and of the Council of 17 December 2013 laying down common provisions on the European Regional Development Fund, the European Social Fund, the Cohesion Fund, the European Agricultural Fund for Rural Development and the European Maritime and Fisheries Fund and laying down general provisions on the European Regional Development Fund, the European Social Fund, the Cohesion Fund and the European Maritime and Fisheries Fund and repealing Council Regulation (EC) No 1083/2006. Official Journal of the European Communities L 347, 20/12/2013. Brussels, Belgium; 2016.

[16] European Commission. Integrated pollution prevention and control. Reference document on the best available techniques for waste incineration. Luxembourg, Luxembourg; 2006.

[17] Lombardi L, Carnevale E, Corti A. A review of technologies and performances of thermal treatment systems for energy recovery from waste. Waste Manag 2015;37:26-44.

[18] Government of the Republic of Serbia. Waste management strategy for the period 2010-2019. Belgrade, Serbia: Official Gazette of the Republic of Serbia No. 29/10; 2010

[19] European Commission. Proposal for a Directive of the European Parliament and of the Council amending Directive 94/62/EC on packaging and packaging waste. Official Journal of the European Union of 1994, L 365. Luxembourg, Luxembourg; 2015.

[20] Government of the Republic of Serbia. Regulation on Defining the Plan for the Reduction of Packaging Waste for the Period from 2015 to 2019. Belgrade, Serbia: Official Gazette of the Republic of Serbia No. 144/14; 2014.

[21] Redzic N, Markovic I. Report on the management of packaging and packaging waste in 2014. Belgrade, Serbia: Serbian Environmental Protection Agency of the Ministry of Agriculture and Environmental Protection of the Republic of Serbia; 2015.

[22] Public Utility Company City Sanitation. Business Report for 2014. Belgrade, Serbia; 2015.

[23] Athanasiou CJ, Tsalkidis DA, Kalogirou E, Voudrias EA. Feasibility analysis of municipal solid waste mass burning in the Region of East Macedonia-Thrace in Greece. Waste Manag Res 2015;33(6):561-9.

[24] Komilis D, Evangelou A, Giannakis G, Lymperis C. Revisiting the elemental composition and the calorific value of the organic fraction of municipal solid wastes. Waste Manag 2012;32(3):372-81.

[25] Riber C, Petersen C, Christensen TH. Chemical composition of material fractions in Danish household waste. Waste Manag 2009;29(4):1251-7.

[26] Christensen TH, editor. Solid waste technology \& management, 2. Chichester, West Sussex, UK: Wiley; 2011.

[27] Rand T, Haukohl J, Marxen U. Municipal solid waste incineration: requirements for a successful project, 462. Washington, DC, USA: World Bank Publications; 2000.

[28] Government of the Republic of Serbia. National action plan for the use of renewable energy sources in the Republic of Serbia. Belgrade, Serbia: Official Gazette of the Republic of Serbia No. 53/13; 2013.

[29] European Commission . Guide to cost-benefit analysis of investment projects. Economic appraisal tool for Cohesion Policy 2014-2020. Luxembourg, Luxembourg: Publications Office of the European Union; 2014.

[30] Pearce D, Atkinson G, Mourato S. Cost-benefit analysis and the environment: recent developments. Paris, France: OECD Publishing; 2006.

[31] National Bank of Serbia. Interest rates of the National Bank of Serbia, 〈http://www. nbs.rs/internet/latinica/30/30 $4 / 30 \quad 4 \quad 5 />$ [accessed 5.01.2016.]

[32] Tsilemou K, Panagiotakopoulos D. Approximate cost functions for solid waste treatment facilities. Waste Manag Res 2006;24(4):310-22.

[33] Bureau of Statistics. Inflation Rate, 〈https://www.statbureau.org/ $\rangle$ [accessed 15.01. 2016.]

[34] Wilson DC, Rodic L, Scheinberg A, Velis CA, Alabaster G. Comparative analysis of solid waste management in 20 cities. Waste Manag Res 2012;30(3):237-54.

[35] Statistical Office of the Republic of Serbia. Population Projections of the Republic of Serbia 2011-2041. Belgrade, Serbia; 2014.

[36] Government of the Republic of Serbia. Regulation on incentives for privileged electric power producers. Belgrade, Serbia: Official Gazette of the Republic of Serbia No. 8/13; 2013.

[37] City of Belgrade. Rescript on granting consent to the decisions amending and modifying the decision on thermal energy prices of the public utility company Belgrade Power Plants. Belgrade, Serbia: Official Gazette of the City of Belgrade No. $56 / 15 ; 2015$.

[38] Government of the Republic of Serbia. Decision on the approval of the price of natural gas for public supply. Belgrade, Serbia: Official Gazette of the Republic of Serbia No. 56/15; 2015.

[39] Public Utility Company Belgrade Power Plants. Business Report for 2014. Belgrade, Serbia; 2015.

[40] Government of the Republic of Serbia. Customs Administration Statistical Bulletin 2014. Customs Administration of the Ministry of Finance. Belgrade, Serbia; 2015

[41] Government of the Republic of Serbia. Law on Mandatory Social Security Contributions. Belgrade, Serbia: Official Gazette of the Republic of Serbia Nos. 84/ 04, 61/05, 62/06, 5/09, 52/11, 101/11, 47/13, 108/13, 57/14, 68/14; $2004-2014$

[42] Statistical Office of the Republic of Serbia. (Ed.) Working activity of the population aged 15 and over by educational attainment in 2015, 〈http://webrzs.stat.gov.rs/ WebSite/> [accessed 17.01.2016.]; 2015.

[43] Djukic M, Jovanoski I, Ivanovic OM, Lazic M, Bodroza D. Cost-benefit analysis of an infrastructure project and a cost-reflective tariff: a case study for investment in wastewater treatment plant in Serbia. Renew Sustain Energy Rev 2016;59:1419-25.

[44] Maynard RL, Walton H, Pollitt F, Fielder R. The impact on health of emissions to air from municipal waste incinerators. Health Protection Agency, London, UK; 2010.

[45] Directive. 2000/76/EC of the European Parliament and of the Council of 4 December 2000 on the incineration of waste. Official Journal of the European Communities L 332, 28/12/2000. Brussels, Belgium; 2010.

[46] Government of the Republic of Serbia. Regulation on the types of waste suitable for thermal treatment, the requirements and criteria for locating thermal treatment facilities, the technical and technological requirements for the design, construction, equipment and operation of the thermal treatment facility, and the treatment of thermal treatment residues. Belgrade, Serbia: Official Gazette of the Republic of Serbia Nos. 102/10, 50/12; 2010- 2012.

[47] Cucchiella F, D'Adamo I, Gastaldi M. Sustainable management of waste-to-energy facilities. Renew Sustain Energy Rev 2014;33:719-28.

[48] Lim SY, Lim KM, Yoo SH. External benefits of waste-to-energy in Korea: a choice experiment study. Renew Sustain Energy Rev 2014;34:588-95.

[49] Secretariat for environmental protection of the City of Belgrade. Local waste management plan for the City of Belgrade 2011-2020. Belgrade, Serbia; 2011. 
[50] Government of the Republic of Serbia. Decision on determining public interest for expropriation, or administrative transfer of property - land and buildings on the land, in order to build facilities for waste management, rehabilitation and expansion of the Vinca landfill in Belgrade. Belgrade, Serbia: Official Gazette of the Republic of Serbia No. 120/14; 2014.
[51] European Investment Bank. The Economic Appraisal of Investment Projects at the EIB. Luxembourg, Luxembourg; 2013.

[52] Fruergaard T, Ekvall T, Astrup T. Energy use and recovery in waste management and implications for accounting of greenhouse gases and global warming contributions. Waste Manag Res 2009;27:724-37. 